\title{
Layered Graphite Prepared by an Ozone Aeration Treatment as an Anode Material for Lithium Ion Batteries
}

\author{
Zhongyi Chen, Yan Liu, Yanzong Zhang ${ }^{*}$, Fei Shen, Gang Yang, Lilin Wang, Xiaohong Zhang, \\ Yan He, Ling Luo, Shihuai Deng \\ College of Environment, Sichuan Agricultural University, Sichuan Engineering and Technical Center \\ for Rural Environmental Protection, Chengdu 611130, Sichuan, PR China \\ *E-mail: yzzhang@sicau.edu.cn
}

doi: $10.20964 / 2018.08 .115$

Received: 5 February 2018 / Accepted: 9 April 2018 / Published: 5 July 2018

\begin{abstract}
Layered graphite was prepared by performing an ozone aeration treatment. The results showed that surface oxidation of the layered graphite formed a unique structure with more exposed ravines and gaps. As the anode material for lithium ion batteries, this graphite exhibited lower diffusion resistance compared with traditional graphite, with an improvement in the performance rate of $40 \%, 50 \%$ and $80 \%$ at $1 \mathrm{C}, 3 \mathrm{C}$ and $5 \mathrm{C}$, respectively. Moreover, the ozone aeration-treated layered graphite electrodes exhibited a higher reversible capacity of $393 \mathrm{mAh} \mathrm{g}^{-1}$ compared to $340 \mathrm{mAh} \mathrm{g}^{-1}$ for layered graphite electrodes and offered better cycling performance compared to traditional graphite, retaining $78 \%$ of the initial reversible capacity after 800 cycles at rate $5 \mathrm{C}$. This exciting discovery based on ozone aeration treatment may provide some novel ideas for improving the performance of graphite electrodes.
\end{abstract}

Keywords: Layered graphite; Ozone aeration; Commercial battery; Electrical properties; Edges and defects

\section{$\underline{\text { FULL TEXT }}$}

(C) 2018 The Authors. Published by ESG (www.electrochemsci.org). This article is an open access article distributed under the terms and conditions of the Creative Commons Attribution license (http://creativecommons.org/licenses/by/4.0/). 